\title{
УДК 616.5-003.871
}

ФЕДОТА О.М. ${ }^{1 凶}$, САДОВНИЧЕНКО Ю.О. ${ }^{1,2}, \quad$ РОЩЕНЮК Л.В. ${ }^{3}, \quad$ ВОРОНЦОВ В.М., РИжкО П.П. ${ }^{3}$

${ }^{1}$ Харківський національний університет імені В.Н. Каразіна,

Україна, 61022, м. Харків, пл. Свободи, 4, e-mail: amsfedota@gmail.com

${ }^{2}$ Харківський наиіональний медичний університет,

Україна, 61022, м. Харків, пр. Науки, 4, е-таil: sadovnychenko@gmail.com

${ }^{3}$ Обласний клінічний шкірно-венерологічний диспансер № 1 ,

Україна, 61052, м. Харків, вул. Благовіщенська, 17, e-mail: okkvd1@ @kr.net

$凶$ amsfedota@gmail.com, (097) 562-44-66

\section{ДОСЛЬДЖЕННЯ ПОШИРЕНОСТІ РІЗНИХ ФОРМ ІХТІОЗУ В ХАРКІВСЬКІЙ ОБЛАСТІ}

Іхтіоз являє собою генетично та клінічно гетерогенну групу порушень процесів зроговіння епідермісу. Його поширеність має географічні відмінності. Мета. Оцінка поширеності іхтіозу у Харківській області. Методи. Збір та аналіз клініко-генеалогічної інформації проводилися методом одиничної реєстрації пробанда на базі Обласного клінічного шкірно-венерологічного диспансеру №1 та шкірно-венерологічних диспансерів Харківської області у 2017 році. Peзультати. Поширеність іхтіозу в Харківської області у 2017 році становила $2,5 \cdot 10^{-4}$. У районах області цей показник варіював від $6,7 \cdot 10^{-5}$ у Красноградському до $1,0 \cdot 10^{-3}$ у Дворічанському. Найнижчою поширеність іхтіозу була серед населення м. Вовчанська $-1,1 \cdot 10^{-4}$, а найвищою у смт. Дворічна $-1,1 \cdot 10^{-3}$. Встановлено відмінності у поширеності іхтіозу звичайного в області у 2008 - 2017 роках. Висновки. Встановлено зниження поширеності іхтіозу у Харківській області в 1,6 раза за останні 10 років. Цей показник для іхтіозу звичайного по області знизився у 1,9 раза за цей же період. Моногенні дерматози на прикладі іхтіозу можуть бути використані як задля моніторингу тягаря спадкової патології у регіоні, так і задля розв'язання проблем загальної й особистої генетичної безпеки населення. Ключові слова: іхтіоз вульгарний, X-зчеплений іхтіоз, поширеність.

Вивчення етнічної та географічної приуроченості моногенних захворювань $є$ важливим в аспекті генетичного моніторингу та генетичного прогнозування для окремих родин [1]. Одним із напрямків дослідження генетичної структури популяцій $є$ вивчення поширеності у них моногенних спадкових захворювань, оскільки порівняння цих показників у різних популяціях та етнічних групах, а також порівняння їх розподілу за віком та статтю дає можливості виявити генетичні відносини між різними популяціями та етносами, встановити зв'язок факторів популяційної динаміки, особливо величин інбридингу та дрейфу генів [1].

До найбільш розповсюджених спадкових захворювань людини належить іхтіоз, дослідження поширеності якого в українських популяціях дало можливість запропонувати його у якості «сторожового» чи «індикаторного» фенотипу [2].

Іхтіоз являє собою генетично та клінічно гетерогенну групу порушень процесів зроговіння епідермісу, які є добре диференційованими i розрізняються за поширеністю. Іхтіоз може бути несиндромальним, лише зі шкірними порушеннями, та синдромальним, коли він $є$ лише одним із численних симптомів [3]. Згідно з МКХ-10, розрізняють чотири несиндромальні форми іхтіозу: загальну (іхтіоз вульгарний, X-зчеплений рецесивний іхтіоз), аутосомно-рецесивний уроджений іхтіоз та кератинопатичні іхтіози.

Іхтіоз простий, або вульгарний $(\mathrm{Q} 80.0$, OMIM 146700) успадковується за аутосомнодомінантним типом із неповною пенетрантністю. Він зумовлений мутаціями у гені епідермального білка філагрину (FLG, OMIM 135940), що розташований у локусі 1q21.3. Мажорними мутаціями цього гена $є$ R501X, 2282del4, 3321delA, Q2417X, E2422X, поширеність яких має значну географічну та етнічну варіабельність. Мутації гена $F L G$ спричинюють зниження вмісту білка профілагрину в зернистому шарі епідермісу, що, у свою чергу, призводить до порушення процесів кератинізації епідермі-

\section{๑ ФЕДОТА О.М., САДОВНИЧЕНКО Ю.О., РОЩЕНЮК Л.В., ВОРОНЦОВ В.М., РИЖКО П.П.}


cy [4].

Мутації у гені стероїдної сульфатази (STS, OMIM 300747), у тому числі мікроделеції, розташовані у локусі Хр22.31, спричинюють X-зчеплений рецесивний іхтіоз (Q 80.1, ОМIM 308100). Первинним ефектом цих мутацій $\epsilon$ накопичення в епідермісі стероїдних сульфатів, яке, у свою чергу, призводить до порушення процесів десквамації зроговілих кератиноцитів та гіперкератозу [5]. Поширеність X-зчепленого рецесивного іхтіозу оцінюється у 1:2000$1: 3000$ [5].

Водночас дані щодо поширеності іхтіозу серед населення різних країн та етносів є обмеженими, тому метою роботи була оцінка поширеності іхтіозу у Харківській області.

\section{Матеріали і методи}

Збір та аналіз клініко-генеалогічної інформації проводилися у 2017 році методом одиничної реєстрації пробанда на базі Обласного клінічного шкірно-венерологічного диспансеру №1 та шкірно-венерологічних диспансерів Харківської області. Діагноз та форма дерматозу встановлені на основі аналізу клініко-генеалогічних даних та результатів лабораторних досліджень відповідно до МКX-10: іхтіоз звичайний (Q 80.0) та X-зчеплений іхтіоз (Q 80.1). Проаналізовано кількість хворих на різні форми іхтіозу у 21 районі Харківської області. Розраховувалися показники поширеності іхтіозу. Статистичний аналіз проводили за допомогою критерію $\chi^{2}[6]$.

\section{Результати та обговорення}

У Харківській області виявлено 249 хворих на іхтіоз, 3 них 78 жінок $(31,3 \%)$ та 171 чоловіків $(68,7 \%)$. Таким чином, поширеність досліджених форм іхтіозу в регіоні дорівнює $2,5 \cdot 10^{-4}$. Однак, за нашими попередніми даними, у 2008 році серед населення Східної України вона становила $3,9 \cdot 10^{-4}$ [7]. Отже, поширеність іхтіозу за останні 10 років знизилася у 1,6 раза $(\mathrm{p}<0,05)$. Ці відмінності, ймовірно, зумовлені ступенем вираженості клінічних форм іхтіозу звичайного [4, 7], інформатизацією суспільства та пов'язаним із ним підвищенням обізнаності пацієнтів щодо догляду за шкірою, а також генетико-демографічними процесами. Зокрема, у Ізюмському районі Харківської області поширеність іхтіозу звичайного знизилася з $3,18 \cdot 10^{-4}$ у 2008 році до $1,48 \cdot 10^{-4}$ у 2017 році.
У районах області сьогодні поширеність іхтіозу загалом варіює від $6,7 \cdot 10^{-5}$ у Красноградському до $1,0 \cdot 10^{-3}$ у Дворічанському. Найнижчі показники поширеності обох досліджених форм іхтіозу були встановлені серед населення м. Вовчанська $-1,1 \cdot 10^{-4}$, а найвищі - у смт. Дворічна $-1,1 \cdot 10^{-3}$. За нашими даними, у 2008 році [2] найвища поширеність усіх форм іхтіозу спостерігалася у с. Жовтневе Красноградського району $-4,8 \cdot 10^{-2}$, а найнижча $4,8 \cdot 10^{-5}$ - у м. Вовчанську. Відмінності за цим показником могли бути зумовлені у томі числі й розвитком транспортної інфраструктури районів області [8].

Найбільш розвинена транспортна інфраструктура (кілометраж доріг із твердим покриттям на квадратний кілометр площі) спостерігається саме у Вовчанському районі - 0,382 км/км ${ }^{2}$, натомість у Дворічанському вона розвинена найгірше $-0,254$ км/км². Тож розбіжності у поширеності іхтіозу у районах Харківській області значною мірою можуть бути пов'язані 3 відмінностями в інфраструктурі районів, які безпосереднім чином впливають на рівень генетичної підрозділеності субпопуляцій [8].

Іхтіоз звичайний був встановлений у 167 пацієнтів, 78 з яких жіночої статі (46,7\%), а 89 чоловічої (53,3\%). Тож поширеність іхтіозу звичайного у Харківській області на сьогодні становить $1,7 \cdot 10^{-4}$, що статистично значуще нижче у 1,9 раза, ніж 10 років тому $(\mathrm{p}<0,05)$ (табл.). Значення цього показника у районах Харківської області коливалося від $3,5 \cdot 10^{-5}$ у Золочівському до $7,8 \cdot 10^{-4}$ у Дворічанському. Визначена поширеність іхтіозу звичайного значно перевищує таку у Білорусі $\left(6,5 \cdot 10^{-5}\right)$ та Боснії й Герцеговині $\left(7,7 \cdot 10^{-6}\right)$, однак суттєво поступається їй в Англії $\left(1,25 \cdot 10^{-2}-4,0 \cdot 10^{-3}\right)(\mathrm{p}<0,05)$ [9-11]. Ці розбіжності можуть бути пов'язані з особливостями географічної поширеності мутацій гена філагрину, ступенем їхньої пенетрантності, етнічного складу населення та клінічним перебігом захворювання. Так, відомо, що у Північній Європі частіше трапляються мутації R501X та $2282 \mathrm{del} 4$ гена $F L G$, а у Південній їх пул поповнюється іншими мутаціями; в азіатів ці мутації трапляються вкрай рідко. Частоти алелів R501X та 2282del4, а також гетерозигот за геном $F L G$ у північній півкулі знижуються 3 півночі на південь від Шотландії до Італії, порівняння поширеності цих мутацій також суттєво варіює $[4,12]$. 
Таблиця. Кількість хворих на іхтіоз у районах Харківської області

\begin{tabular}{|c|c|c|c|c|}
\hline \multirow[b]{2}{*}{ Район } & \multicolumn{2}{|c|}{2008 p. } & \multicolumn{2}{|c|}{2017 p. } \\
\hline & $\begin{array}{c}\text { Іхтіоз } \\
\text { звичайний, } \\
\text { x }\left(10^{-5}\right)\end{array}$ & $\begin{array}{c}\text { X-зчеплений } \\
\text { ixтіоз, } \\
\text { x }\left(10^{-5}\right)^{*}\end{array}$ & $\begin{array}{c}\text { Іхтіоз } \\
\text { звичайний, } \\
\text { x }\left(10^{-5}\right)\end{array}$ & $\begin{array}{c}\text { X-зчеплений } \\
\text { iхтіоз, } \\
\text { x }\left(10^{-5}\right)^{*}\end{array}$ \\
\hline Балаклійський & 35,1 & 20,3 & 21,9 & 28,5 \\
\hline Близнюківський & 56,0 & 10,1 & 41,7 & 0,0 \\
\hline Богодухівський & 41,5 & 15,9 & 56,2 & 32,7 \\
\hline Валківський & 27,2 & 6,6 & 24,9 & 26,6 \\
\hline Вовчанський & 12,1 & 17,5 & 10,7 & 9,2 \\
\hline Дворічанський & 78,7 & 45,6 & 78,7 & 48,6 \\
\hline Зміївський & 18,9 & 8,8 & 8,4 & 24,2 \\
\hline Золочівський & 3,5 & 15,1 & 7,6 & 8,1 \\
\hline Ізюмський & 31,8 & 3,0 & 14,8 & 13,3 \\
\hline Кегичівський & 13,6 & 0,0 & 19,0 & 0,0 \\
\hline Красноградський & 21,6 & 4,7 & 4,5 & 4,9 \\
\hline Куп’янський & 9,4 & 0,0 & 6,1 & 18,9 \\
\hline Лозівський & 11,0 & 4,3 & 6,3 & 13,7 \\
\hline Нововодолазький & 53,2 & 24,3 & 36,1 & 37,7 \\
\hline Первомайський & 26,6 & 0,0 & 12,7 & 0,0 \\
\hline Шевченківський & 32,7 & 10,2 & 14,6 & 20,5 \\
\hline
\end{tabular}

Примітка. * - показник розраховувався лише на осіб чоловічої статі.

Це явище може мати адаптивний характер через збільшення проникності шкіри для ультрафіолетового випромінювання та зумовленого ним підвищення рівня вітаміну D у плазмі крові, особливо у країнах з низькою інсоляцією $[4,13]$. Якщо мутація 2282del4 у гетерозиготі має повну пенетрантність, то в мутації R501X вона коливається від $80 \%$ до $100 \%$, хоча важкість клінічного перебігу іхтіозу за цих мутацій не оцінювалася [4]. Дослідження етнічних відмінностей поширеності іхтіозу показало, що у Чувашії серед адигів поширеність іхтіозу становить $1,0 \cdot 10^{-}$ , , тоді як серед марійців $-7,0 \cdot 10^{-4}[1]$.

Поширеність Х-зчепленого рецесивного іхтіозу у Харківській області становила $1,5 \cdot 10^{-4}$ чоловіків, що нижче від ізраїльського та європейського показників $\left(7,7 \cdot 10^{-4}\right.$ та $3,3 \cdot 10^{-4}$ $5,0 \cdot 10^{-4}$ відповідно), однак значно вище від цього показника у Ростовській області Російської Федерації $\left(6,4 \cdot 10^{-5}\right)$ та у Білорусі $\left(1,1 \cdot 10^{-5}\right)[9,11$, $14,15]$. У трьох районах області натепер не зареєстровано жодного пацієнта $3 \mathrm{X}$-зчепленим рецесивним іхтіозом, у Красноградському райо- ні він становить $4,7 \cdot 10^{-5}$ чоловіків, а у Дворічанському $-4,9 \cdot 10^{-4}$ чоловіків. Ці відмінності також можуть бути зумовлені як інфраструктурою популяцій, так і етнічною приуроченістю, зокрема у Каліфорнії вона була у 1,46 раза більша серед азіатів, ніж серед білого населення [16].

\section{Висновки}

Встановлено зниження поширеності іхтіозу у Харківській області та по іiі районах у 1,6 раза за останні 10 років. Цей показник для іхтіозу звичайного по області знизився у 1,9 раза за цей же період. Моногенні дерматози на прикладі іхтіозу можуть бути використані як задля моніторингу тягаря спадкової патології у регіоні, так і задля розв'язання проблем загальної й особистої генетичної безпеки населення.

Дослідження проводилося в рамках науководослідної роботи ХНУ імені В.Н. Каразіна «Генетичні передумови розвитку та корекиії спадкової патологї на різних етапах онтогенезу людини та тварин» (2016-2017 рр.), № держ. реєстраиіï $0116 U 005341$.

\section{Література}

1. Гинтер Е.К., Зинченко Р.А. Наследственные болезни в российских популяциях. Вестник ВОГиС. 2006. Т. 10 , № 1. С. $106-125$.

2. Федота О.М. Генодерматози в дослідженні проблем генетичної безпеки людини: автореф. дис. ... докт. біол. наук: спец. К., 2012. 40 с. 
3. Oji V., Tadini G., Akiyama M., Blanchet Bardon C., Bodemer C., Bourrat E., Coudiere P., DiGiovanna J.J., Elias P., Fisher J., Fleckman P., Gina M., Harper J., Hashimoto T., Hausser I., Hennies H.C., Hohl D., Hovnanian A., Ishida-Yamamoto A., Jacyk W.K., Leachman S., Leigh I., Mazereeuw-Hautier J., Milstone L., Morice-Picard F., Paller A.S., Richard G., Schmuth M., Shimizu H., Sprecher E., Van Steensel M., Taïeb A., Toro J.R., Vabres P., Vahlquist A., Williams M., Traupe H. Revised nomenclature and classification of inherited ichthyoses: results of the First Ichthyosis Consensus Conference in Sorèze 2009. J. Am. Acad. Dermatol. 2010. Vol. 63, № 4. P. 607-41. doi: 10.1016/j.jaad.2009.11.020.

4. Filaggrin: Basic science, epidemiology, clinical aspects and management. Eds. J.P. Thyssen, H.I. Maibach. Berlin, Heidelberg: Springer, 2014. 373 p. doi: 10.1007/978-3-642-54379-1.

5. Elias P.M., Williams M.L., Crumrine, D., Schmuth M. Ichthyoses: Clinical, Biochemical, Pathogenic and Diagnostic Assessment. Current Problems in Dermatology. 2010. Vol. 39. 146 p. doi: 10.1159/isbn.978-3-8055-9395-3.

6. Атраментова Л.О., Утєвська О.М. Статистичні методи в біології: Підручник. Харків: ХНУ імені В.Н. Каразіна, 2007. $288 \mathrm{c}$.

7. Brown S.J., McLean W.H. One remarkable molecule: filaggrin. J. Invest. Dermatol. 2012. Vol. 132, № 3, Pt. 2 . P. $751-762$. doi: 10.1038/jid.2011.393.

8. Федота А.М., Гавилей Н.С., Полтавская А.Ю. Генодерматозы как маркеры генетической отягощенности подразделенных популяций с различными показателями инфраструктуры. Фактори експериментальної еволюиії організмів. 2010. T. 9. C. $459-463$.

9. Амелина С.С., Ветрова Н.В., Дегтерева Е.В., Амелина М.А., Петрова Н.В., Васильева Т.А., Зинченко Р.А. Разнообразие наследственных заболеваний кожи у населения Ростовской области. Валеология. 2014. № 4. С. 12-17.

10. Мутевелич-Арсланагич Н. Генодерматозы на территории Республики Боснии и Герцеговины. Вестн. дерматологии $u$ венерологии. 1992. № 4. С. 40-42.

11. Сукало А.В., Жидко Л.Б., Лазарь Е.А. Врожденный ихтиоз у детей. Минск: Беларус. наука, 2013. 70 с.

12. Федота А.М., Рощенюк Л.В., Садовниченко Ю.А., Меренкова И.Н., Гонтарь Ю.В., Воронцов В.М. Анализ генов одноуглеродного метаболизма и комплекса эпидермальной дифференцировки у больных ихтиозом простым. Georgian Medical News. 2017. № 3 (264). C. 90-97.

13. Thyssen J.P., Bikle D.D., Elias P.M. Evidence that loss-of-function filaggrin gene mutations evolved in Northern Europeans to favor intracutaneous vitamin D3 production. Evol. Biol. 2014. Vol. 41, № 3. P. 388-396. doi: 10.1007/s11692-014-9282-7.

14. David M., Israel N., Merksamer R., Bar-Nizan N., Borochowitz Z., Bar-el H., Yehudai I., Dar H. Very low maternal serum unconjugated estriol and prenatal diagnosis of steroid sulfatase deficiency. Fetal. Diagn. Ther. 1995. Vol. 10, № 2. P. 76-79. doi: $10.1159 / 000264207$.

15. Oji V. Ichthyosis vulgaris von X-chromosomal rezessiver Ichthyose unterscheiden. hautnah dermatologie. 2017. Vol. 33 , № 5. P. 40-43. doi: 10.1007/s15012-017-2523-6.

16. Craig W.Y., Robertson M., Palomaki G.E., Marcos J., Haddow J.E. Prevalence of steroid sulfatase deficiency in California according to race and ethnicity. Prenat. Diagn. 2010. Vol. 30, № 9. P. 893-898. doi: 10.1002/pd.2588.

\section{References}

1. Ginter E.K., Zinchenko R.A. hereditary diseases in Russian populations. Vestnyk VOHyS. 2006. Vol. 10, № 1. P. 106-125.

2. Fedota A.M. Genodermatosis in the study of the problems of human genetic safety. The dissertation thesis ... doctor of biological sciences. Kyiv, 2012. 40 p.

3. Oji V., Tadini G., Akiyama M., Blanchet Bardon C., Bodemer C., Bourrat E., Coudiere P., DiGiovanna J.J., Elias P., Fisher J., Fleckman P., Gina M., Harper J., Hashimoto T., Hausser I., Hennies H.C., Hohl D., Hovnanian A., Ishida-Yamamoto A., Jacyk W.K., Leachman S., Leigh I., Mazereeuw-Hautier J., Milstone L., Morice-Picard F., Paller A.S., Richard G., Schmuth M., Shimizu H., Sprecher E., Van Steensel M., Taïeb A., Toro J.R., Vabres P., Vahlquist A., Williams M., Traupe H. Revised nomenclature and classification of inherited ichthyoses: results of the First Ichthyosis Consensus Conference in Sorèze 2009. J. Am. Acad. Dermatol. 2010. V. 63, № 4. P. 607-41. doi: 10.1016/j.jaad.2009.11.020.

4. Filaggrin: Basic science, epidemiology, clinical aspects and management. Eds. J.P. Thyssen, H.I. Maibach. Berlin, Heidelberg: Springer, 2014. 373 p. doi: 10.1007/978-3-642-54379-1.

5. Elias P.M., Williams M.L., Crumrine, D., Schmuth M. Ichthyoses: Clinical, Biochemical, Pathogenic and Diagnostic Assessment. Current Problems in Dermatology. 2010. V. 39. 146 p. doi: 10.1159/isbn.978-3-8055-9395-3.

6. Atramentova L.O., Utievs'ka O.M. Statystychni metody v biolohiï: Pidruchnyk. Kharkiv: KhNU imeni V.N. Karazina, 2007. $288 \mathrm{p}$.

7. Brown S.J., McLean W.H. One remarkable molecule: filaggrin. J. Invest. Dermatol. 2012. Vol. 132, № 3, Pt. 2. P. $751-762$. doi: 10.1038/jid.2011.393.

8. Fedota A.M., Gaviley N.S., Poltavskaya A.Yu. Genodermatozyi kak markeryi geneticheskoy otyagoschennosti podrazdelennyih populyatsiy s razlichnyimi pokazatelyami infrastrukturyi. Topics in experimental evolution of organisms. 2010. T. 9. C. $459-463$.

9. Amelina S.S., Vetrova N.V., Degtereva E.V., Amelina M.A., Petrova N.V., Vasilieva T.A., Zinchenko R.A. Variety of hereditary skin diseases in Rostov Region population. Valeology. 2014. № 4. P. 12-17.

10. Mutevelich-Arslanagich N. Genodermatozyi na territorii Respubliki Bosnii i Gertsegovinyi. Vestnik dermatologii $i$ venerologii. 1992. № 4. P. 40-42.

11. Sukalo A.V., Zhidko L.B., Lazar E.A. Vrozhdennyiy ihtioz u detey. Minsk: Belarus. nauka, 2013. 70 p.

12. Fedota O.M., Roshchenyuk L.V., Sadovnychenko I.A., Merenkova I.N., Gontar I.V., Vorontsov V.M. Analysis of one-carbon metabolism genes and epidermal differentiation complex in patients with ichthyosis vulgaris. Georgian Medical News. 2017. № 3 (264). P. 90-97. 
13. Thyssen J.P., Bikle D.D., Elias P.M. Evidence that loss-of-function filaggrin gene mutations evolved in Northern Europeans to favor intracutaneous vitamin D3 production. Evol. Biol. 2014. Vol. 41, № 3. P. 388-396. doi: 10.1007/s11692-014-9282-7.

14. David M., Israel N., Merksamer R., Bar-Nizan N., Borochowitz Z., Bar-el H., Yehudai I., Dar H. Very low maternal serum unconjugated estriol and prenatal diagnosis of steroid sulfatase deficiency. Fetal. Diagn. Ther. 1995. Vol. 10, № 2. P. 76-79. doi: $10.1159 / 000264207$.

15. Oji V. Ichthyosis vulgaris von X-chromosomal rezessiver Ichthyose unterscheiden. hautnah dermatologie. 2017. Vol. 33 , № 5. P. 40-43. doi: 10.1007/s15012-017-2523-6.

16. Craig W.Y., Robertson M., Palomaki G.E., Marcos J., Haddow J.E. Prevalence of steroid sulfatase deficiency in California according to race and ethnicity. Prenat. Diagn. 2010. Vol. 30, № 9. P. 893-898. doi: 10.1002/pd.2588.

FEDOTA O.M. ${ }^{1}$, SADOVNYCHENKO I.O..$^{1,2}$, ROSHCHENYUK L.V. ${ }^{3}$, VORONTSOV V.M. ${ }^{3}$, RYZHKO P.P. ${ }^{3}$

${ }^{1}$ V.N. Karazin Kharkiv National University,

Ukraine, 61022, Kharkiv, Svobody sq., 4, e-mail: Omfedota@karazin.ua

${ }^{2}$ Kharkiv National Medical University,

Ukraine, 61022, Kharkiv, Nauky ave, 4, e-mail: sadovnychenko@gmail.com

${ }^{3}$ Regional Clinical Dispensary for Skin and Venereal Diseases»,

Ukraine, 61052, Blagovishchenska str., 17, e-mail: okkvd1@ukr.net

\section{STUDY OF PREVALENCE OF DIFFERENT FORMS OF ICHTHYOSIS IN KHARKIV REGION}

Ichthyosis is genetically and clinically heterogenic group of epidermis keratinization disorders. Its prevalence is geographically different. Aim. The aim of this research was to evaluate ichthyosis prevalence in Kharkiv region. Methods. The collection of clinical-genealogical history was carried out by the method of single registration of the proband on the basis of the Regional Clinical Dermatological and Venereological Health Center No. 1 and the Dermatovenerological Health Centers of the Kharkiv Region in 2017. Results. The ichthyosis prevalence in Kharkiv region was $2.5 \cdot 10^{-4}$ in 2017. The ichthyosis prevalence varied from $6.7 \cdot 10^{-5}$ in Krasnohrad district to $1.0 \cdot 10^{-3}$ in Dvorichna district. The least prevalence was in the population of Vovchansk city $\left(1.1 \cdot 10^{-4}\right)$ and the highest one was in the population of Dvorichna city $\left(10.7 \cdot 10^{-4}\right)$. The differences between the prevalence of ichthyosis vulgaris in Kharkiv region in 2008-2017 were established. Conclusions. It was found that the decrease of ichthyosis prevalence in Kharkiv region was 1.6 times during last 10 years. This index for ichthyosis vulgaris was decreased 1.9 times at the same period. Monogenic dermatoses, as an example of ichthyosis, can be used both to monitor the burden of genetic disorders in the region and to solve the problems of general and personal genetic safety in the population.

Keywords: ichthyosis vulgaris, X-linked recessive ichthyosis, prevalence. 